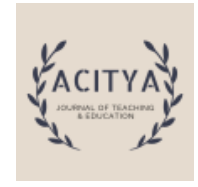

Acitya: Journal of Teaching \& Education, Vol. 3 No. 12021

Acitya: Journal of Teaching \& Education

Website: http://journals.umkt.ac.id/index.php/acitya

Research Papers, Review Papers, and Research Report

Kampus 1 UMKT Jl. Ir. H. Juanda No 15, Samarinda, Indonesia 75123

\title{
BIOLOGICAL LEARNING ADAPTATION DURING THE COVID-19 PANDEMIC PERIOD IN PONOROGO 1 PUBLIC HIGH SCHOOL
}

\author{
Sukardi ${ }^{1}$, Isra' Indar Handayani ${ }^{2}$, Nawawi ${ }^{3}$ \\ ${ }^{1}$ SMA NEGERI 1 PONOROGO \\ ${ }^{2}$ SMA NEGERI 1 SAMBIT PONOROGO \\ ${ }^{3}$ IKIP PGRI Pontianak \\ Email: nawawi@ikippgriptk.ac.id
}

\begin{abstract}
This study aims to determine the description of the adaptations that students have made to online learning during the Covid-19 pandemic in biology subjects at Ponorogo 1 Public High School. The research method used is a descriptive quantitative method with data collection carried out through an online questionnaire using google formula to 361 students of Ponorogo 1 Public High School from Class X, XI, and XII MIPA related to the implementation of online biology learning. Based on online questionnaires, $67.31 \%$ of respondents stated that they had difficulty understanding the learning material because they did not meet the teacher directly so that $50.14 \%$ of respondents tried to always come on time for online learning. The application most liked by $68.70 \%$ of respondents is google classroom. While $93.91 \%$ of respondents have been able to implement independent learning, $77.56 \%$ of respondents feel happy with online learning. Based on the results of the analysis, biology teachers at Ponorogo 1 Public High School became more creative and innovative in utilizing online media, which had an impact on increasing the ability to learn independently and the ability to master the technology of student at Ponorogo 1 Public High School.
\end{abstract}

Keywords: Biology Learning, Adaptation, Pandemic Period

\section{INTRODUCTION}

The Covid-19 pandemic had a significant impact on the education sector in Indonesia, and the Ministry of Education and Culture of the Republic of Indonesia responded to the effect of the Covid-19 pandemic by issuing regulations and learning guides during the Covid-19 pandemic,, namely; (1) Circular of the Minister of Education and Culture Number 4 of 2020 dated March 20, 2020 concerning Implementation of Education Policies in an Emergency Period for the Spread of Corona Virus Disease (Covid-19), (2) Circular of the Secretary General of the Ministry of 
Education and Culture Number 15 of 2020 concerning Guidelines for Implementation of Learning from Home, (3) Joint Decree of the Minister of Education, Minister of Religion, Minister of Health and Minister of Home Affairs regarding guidelines for implementing learning in 2020-2021 and the academic year 2020-2021, and (4) Decree of the Minister of Education and Culture Number 719/P/2020 which explains the implementation curriculum in educational units in special conditions. The purpose of the issuance of regulations and technical guidelines for learning during the Covid 19 pandemic in Indonesia is to ensure optimal educational services for students even though they are faced with various challenges.

At Ponorogo 1 Public High School, the implementation of Distance Learning was carried out under the Ponorogo Regent Circular Number 445 / 9591405.26 / 2020 on Compliance with Government Policies in Handling the Spread of the Corona Virus (Covid19) in the Government of the Ponorogo Regency, where online learning is required to implement in Kindergarten, SD, SMP, and SMA. At the beginning of the implementation of Distance Learning, which was carried out by Biology teachers at Ponorogo 1 Public High School, biology teachers had identified some of the technical issues related to the implementation of online learning, such as; 1) difficulty finding the right learning platform, 2) unstable internet signal constraints, 3) smartphone / laptop ownership, 3) quota purchase costs. The obstacles experienced are in line with (Negara, Ibrahim, \& Etmy, 2020) learning during the pandemic is constrained by the lack of experience of teachers in the online learning process. The internet quota runs out to download online assignment information in the form of documents or videos (Sari, Nawawi, \& Darmawan, 2020).

Social Media and particularly, online learning is an important component of education higher education (Jill, Wang, \& Mattia, 2019). In line with (Sari, 2020) Youtube as a solution alternative learning media to improve the quality of teacher teaching during the pandemic Covid19. Meanwhile (DeWitt, Alias, Siraj, Yaakub, Ayob \& Ishak, 2013) Youtube and Google Classroom is effective for learning because learners can develop higher-level thinking skills such as decision making and problem-solving, as well as communicate and collaborate using social media. The purpose of this study was to describe the adaptation that students have made to online learning during the Covid-19 pandemic in biology subjects at Ponorogo 1 Public High School.

\section{METHOD}

The research method used is a descriptive quantitative method with data collection carried out through an online questionnaire using google formula to students of Ponorogo 1 Public High School in Class X, XI and XII MIPA related to the implementation of online biology learning. 
Secondary data were collected through electronic media and various journals relevant to the research. The subjects of this study were 361 students of Ponorogo 1 Public High School who had implemented online learning. Data analysis was performed using the analysis model of Miles \& Huberman (1994) which consists of three stages, namely; data reduction, data display, and conclusion drawing and verification.

\section{FINDINGS AND DISCUSSION}

Ponorogo 1 Public High School had implemented online learning according to instructions from the Ministry of Education and Culture of the Republic of Indonesia during the Covid-19 pandemic in 2020. The results of the Biology Learning Analysis are based on the results of an online response questionnaire that had been developed by lecturers in the Biology Education Study Program IKIP PGRI Pontianak. Respondents of this study were 361 students from class X, XI and XII MIPA Ponorogo 1 Public High School. The results of the response questionnaire related to the obstacles faced by Ponorogo 1 Public High School students in online learning during the Covid19 pandemic can be seen in Table 1.

Table 1. Questionnaire for Obstacles in Learning Biology Online at Ponorogo 1 Public High School during the pandemic (Covid-19)

\begin{tabular}{|c|c|c|c|}
\hline Questionnaire & Student Response & $\begin{array}{l}\text { Number of } \\
\text { Respondents }\end{array}$ & $\begin{array}{l}\text { Percentage } \\
\text { of }\end{array}$ \\
\hline \multirow{6}{*}{$\begin{array}{l}\text { Constraints faced during } \\
\text { online learning in } \\
\text { biology subjects carried } \\
\text { out at Ponorogo } 1 \text { Public } \\
\text { High School }\end{array}$} & Internet Quota Very Wasteful & 48 & $13.30 \%$ \\
\hline & $\begin{array}{l}\text { Lack of understanding the Online } \\
\text { Learning Applications used }\end{array}$ & 12 & $3.32 \%$ \\
\hline & Difficulty getting Internet access & 22 & $6.09 \%$ \\
\hline & $\begin{array}{l}\text { Difficulty understanding the } \\
\text { material because they do not meet } \\
\text { face to face with the teacher }\end{array}$ & 243 & $67.31 \%$ \\
\hline & $\begin{array}{l}\text { There are no friends to discuss } \\
\text { when learning online }\end{array}$ & 36 & $9.97 \%$ \\
\hline & Total & 361 & $100 \%$ \\
\hline \multirow{2}{*}{$\begin{array}{l}\text { Students In taking } \\
\text { online } \\
\text { according to the given } \\
\text { schedule }\end{array}$} & $\begin{array}{l}\text { punctualityAlways following on } \\
\text { time }\end{array}$ & 181 & $50.14 \%$ \\
\hline & Sometimes on time & 162 & $44.88 \%$ \\
\hline
\end{tabular}




\begin{tabular}{|c|c|c|c|}
\hline Questionnaire & Student Response & $\begin{array}{l}\text { Number of } \\
\text { Respondents }\end{array}$ & $\begin{array}{c}\text { Percentage } \\
\text { of }\end{array}$ \\
\hline & Often late & 15 & $4.16 \%$ \\
\hline & Often late & 3 & $0,83 \%$ \\
\hline & Total & 361 & $100 \%$ \\
\hline \multirow{5}{*}{$\begin{array}{l}\text { Based on the obstacles } \\
\text { encountered, agree if the } \\
\text { online learning carried } \\
\text { out again in the next } \\
\text { semester }\end{array}$} & Strongly Agree & 41 & $11.36 \%$ \\
\hline & Agree & 70 & $19.39 \%$ \\
\hline & Disagree & 146 & $40.44 \%$ \\
\hline & Strongly Disagree & 104 & $28.81 \%$ \\
\hline & Total & 361 & $100 \%$ \\
\hline
\end{tabular}

Based on the results of the student response questionnaire in table 1 it can be seen that 243 students or $67.31 \%$ of respondents stated that it was difficult to understand the learning material provided online because they did not meet directly with the teacher, while 48 students or $13.30 \%$ of respondents felt that the internet quota to be very wasteful. Meanwhile, 36 students or $9.97 \%$ of respondents stated that when online learning was carried out, they felt that there were no friends to discuss with, so that it became an obstacle for some students to understand the material and assignments presented. The various geographical conditions in Ponorogo Regency caused 22 students or $6.09 \%$ to experience difficulties in getting internet access. In line with (Purwanto, Pramono, Asbari, Hyun, Wijayanti, \& Putri, 2020) there are several obstacles experienced by students, teachers and parents in online teaching and learning activities, namely the mastery of technology is still lacking, additional internet quota costs, additional jobs for people parents in accompanying children to learn, communicate and socialize between students,

Online learning does not reduce students' enthusiasm to always be present on time, this is supported by 181 students or 50.14 respondents who always arrive on time according to the shared schedule. While there are still around $44.88 \%$ of respondents or 162 students who are late in taking online learning. Meanwhile, 18 students stated that they were often late in taking online learning because of several obstacles such as; there is no signal, internet quota runs out, do not have a cell phone or change cell phones with their parents. 
Various obstacles experienced by students caused 250 students or $69.25 \%$ of respondents to disagree if the implementation of distance learning was extended. However, there were 101 students or $30.75 \%$ of respondents agreed that the learning was extended. This is possible because students feel comfortable with the implementation of distance learning, have internet access and facilities for laptops or cellphones that can be used at home for the smooth running of distance learning. Student responses to learning and applications used can be seen in Table 2.

Table 2.Impression Response Questionnaire and Online Learning Application at Ponorogo 1 Public High School during the pandemic (Covid-19)

\begin{tabular}{|c|c|c|c|}
\hline Questionnaire & Student Response & $\begin{array}{l}\text { Number of } \\
\text { Respondents }\end{array}$ & Percentage \\
\hline \multirow{5}{*}{$\begin{array}{l}\text { Impressions of Ponorogo } 1 \text { Public High } \\
\text { School students regarding the } \\
\text { implementation of online learning } \\
\text { during the pandemic period }\end{array}$} & Very enjoyable & 17 & $4.71 \%$ \\
\hline & Fun & 280 & $77.56 \%$ \\
\hline & Not fun & 47 & $13.02 \%$ \\
\hline & Very unpleasant & 17 & $4.71 \%$ \\
\hline & Total & 361 & $100 \%$ \\
\hline \multirow{4}{*}{$\begin{array}{l}\text { Applications that are often used by } \\
\text { biology teachers at Ponorogo } 1 \text { Public } \\
\text { High School during online learning }\end{array}$} & Whatsapp group & 27 & $7.48 \%$ \\
\hline & Zoom & 38 & $10.53 \%$ \\
\hline & Google Classroom & 296 & $81.99 \%$ \\
\hline & Total & 361 & $100 \%$ \\
\hline \multirow{4}{*}{$\begin{array}{l}\text { application most liked by students in } \\
\text { online learning }\end{array}$} & Whatsapp groups & 55 & $15.24 \%$ \\
\hline & Zoom & 58 & $16.07 \%$ \\
\hline & Google Classroom & 248 & $68,70 \%$ \\
\hline & Total & 361 & $100 \%$ \\
\hline \multirow[t]{2}{*}{$\begin{array}{l}\text { Biology Teachers Use A Variety of } \\
\text { Learning Media in Online Learning in } \\
\text { Ponorogo } 1 \text { Public High School }\end{array}$} & $\begin{array}{l}\text { Often use various } \\
\text { media in teaching } \\
\text { online }\end{array}$ & 51 & $14.13 \%$ \\
\hline & $\begin{array}{l}\text { Often use various } \\
\text { media in online } \\
\text { teaching }\end{array}$ & 202 & $55.96 \%$ \\
\hline
\end{tabular}




\begin{tabular}{llcc}
\hline Questionnaire & Student Response & $\begin{array}{c}\text { Number of } \\
\text { Respondents }\end{array}$ & Percentage \\
\hline & $\begin{array}{l}\text { Rarely use various } \\
\text { media in online } \\
\text { learning }\end{array}$ & 101 & $27.98 \%$ \\
\cline { 2 - 4 } & $\begin{array}{l}\text { Only use 1 type of } \\
\text { media }\end{array}$ & 7 & $1.94 \%$ \\
\cline { 2 - 4 } & Total & $\mathbf{3 6 1}$ & $\mathbf{1 0 0 \%}$ \\
\hline
\end{tabular}

No matter how sophisticated the technology is, it will not be able to replace the teacher's role in learning. The learning process is not just a transfer of knowledge but also a transformation of values. Teachers during the pandemic have changed the face-to-face learning method to online learning, based on the results of student responses, information is obtained that 248 students or $68.70 \%$ of respondents stated that the most preferred application in online learning is Google Classroom, while other applications are zoom and WhatsApp group. While biology teachers at Ponorogo 1 Public High School prefer to use the Google Classroom application, this is supported by the results of a response questionnaire where $81.99 \%$ of respondents or 296 students stated that the teacher used the Google Classroom application in learning, and other applications used were Zoom and WhatsApp group. This is in line with research (Suhada, Kurniati, Pramadi, \& Listiawati, 2020) that the use of the Google Classroom application in online learning during the Covid-19 outbreak is quite good and effective, it's just that it will be better if combined with other online platforms.

The use of the Google Classroom application is able to create a classroom atmosphere even though learning is carried out online, this is indicated by 280 students or $77.56 \%$ of respondents who feel happy with online learning. Meanwhile, synchronous hybrid learning is able to create a more flexible and attractive learning environment compared to classroom learning (Raes, Detienne, Windey, \& Depaepe, 2020). One of the reasons students prefer online learning is because the teacher uses a variety of learning media (more than 1 type of learning media) than offline learning at school, this is indicated by the results of a questionnaire where 202 students or $55.96 \%$ of respondents stated that the teacher used a variety of media in teaching, as for the forms of media used, among others; Biology material videos from YouTube, PowerPoint presentation videos made by biology teachers, materials and questions in the form of documents (PDF or DOC), quizzes, google forms, and the Kemdikbud learning vlab. The results obtained are similar to research 
conducted in Poland (Rizun \& Strzelecki, 2020) which states that students have a moderate feeling that distance learning had increased their effectiveness and productivity. Student learning motivation and understanding of material during the pandemic can be seen in Table 3 .

Table 3. Motivation Questionnaire and Understanding of Online Learning materials at Ponorogo 1 Public High School during the pandemic (Covid-19)

\section{Questionnaire \\ Student Response \\ Number of Respondents \\ Percentage}

Online Learning encourages students to be more independent in learning biology

$71 \quad 19.67 \%$

Agree

\begin{tabular}{|c|c|c|c|}
\hline & \multirow{3}{*}{$\begin{array}{l}\begin{array}{l}\text { Strongly } \\
\text { Agree }\end{array} \\
\text { Agree }\end{array}$} & \multirow[b]{2}{*}{178} & \multirow[b]{2}{*}{$49,31 \%$} \\
\hline & & & \\
\hline & & 90 & $24.93 \%$ \\
\hline & Disagree & 22 & $6.09 \%$ \\
\hline & Total & 361 & $100 \%$ \\
\hline \multirow{5}{*}{$\begin{array}{l}\text { Online learning encourages students to master } \\
\text { technology such as google classrooms, zoom } \\
\text { and other learning applications }\end{array}$} & $\begin{array}{l}\text { Strongly } \\
\text { Agree }\end{array}$ & 132 & $36.57 \%$ \\
\hline & $\begin{array}{l}\text { Strongly } \\
\text { Agree }\end{array}$ & 179 & $49,58 \%$ \\
\hline & Agree & 32 & $8.86 \%$ \\
\hline & Disagree & 18 & $4.99 \%$ \\
\hline & Total & 361 & $100 \%$ \\
\hline \multirow{5}{*}{$\begin{array}{l}\text { Online learning encourages students to better } \\
\text { communicate and collaborate with friends in } \\
\text { doing assignments given by the teacher online }\end{array}$} & $\begin{array}{l}\text { Strongly } \\
\text { Agree Once }\end{array}$ & 50 & $13.85 \%$ \\
\hline & $\begin{array}{l}\text { Strongly } \\
\text { Agree }\end{array}$ & 157 & $43,49 \%$ \\
\hline & Agree & 116 & $32.13 \%$ \\
\hline & Disagree & 38 & $10.53 \%$ \\
\hline & Total & 361 & $100 \%$ \\
\hline \multirow[t]{2}{*}{$\begin{array}{l}\text { Students understand the material presented by } \\
\text { the teacher in online learning }\end{array}$} & $\begin{array}{l}\text { Strongly } \\
\text { understand }\end{array}$ & 145 & $40.17 \%$ \\
\hline & Understand & 169 & $46.81 \%$ \\
\hline
\end{tabular}

Online learning encourages students to master technology such as google classrooms, zoom and other learning applications 


\begin{tabular}{llcc}
\hline Questionnaire & \multicolumn{1}{c}{$\begin{array}{c}\text { Student } \\
\text { Response }\end{array}$} & $\begin{array}{c}\text { Number of } \\
\text { Respondents }\end{array}$ & Percentage \\
\hline & $\begin{array}{l}\text { Do not } \\
\text { understand }\end{array}$ & 40 & $11.08 \%$ \\
\cline { 2 - 4 } & $\begin{array}{l}\text { Strongly Don't } \\
\text { Understand }\end{array}$ & 7 & $1.94 \%$ \\
\cline { 2 - 4 } & Total & $\mathbf{3 6 1}$ & $\mathbf{1 0 0 \%}$ \\
\hline
\end{tabular}

Distance learning that had been implemented, give an impact on student learning independence, this is supported by the results of a questionnaire where there are $93.91 \%$ of respondents or 339 students feel that online learning encourages students to be more independent in learning biology and students become more active in finding solutions to assignments online given. Ponorogo 1 Public High School students feel that their ability to master technology and information such as the use of the Google Classroom application, Zoom and other learning applications had increased, this is supported by the results of a questionnaire where $95.01 \%$ of respondents or 343 students felt the positive impact of online learning at Ponorogo 1 Public High School. E-learning can change the roles of teachers and students because it is more attractive and able to increase the clarity of teaching and increase the individualization of the learning process and feedback (Kacetl, \& Semradova, 2020).

Students' communication skills also improve, because students have to communicate virtually with their friends in a group who are in different locations. Online learning had encouraged students to further improve their ability to communicate and collaborate with friends online in doing assignments given by the teacher in Google Classroom and WhatsApp class group. As many as 314 students or $86.98 \%$ of respondents felt that the material provided online was easy to understand. Meanwhile, there were 47 students or $13.02 \%$ of respondents who did not understand the material presented by the teacher online.

\section{CONCLUSIONS}

Barriers encountered by Ponorogo 1 Public High School students in implementing online learning to include, such as; difficulty understanding material, quotas, and internet access, lack of understanding of online applications, and lack of friends to talk to. Ponorogo 1 Public High School students learn online on schedule. The most preferred online learning applications for teachers and 
students are Google Classroom, Zoom, and WhatsApp groups. Teachers are more creative and innovative in use of online learning media that influence the increased independence, the understanding of technology, and the communication skills of students. Ponorogo 1 Public High School students prefer online learning, and the material presented by biology teachers in online learning is easy to understand.

\section{REFERENCES}

DeWitt, D., Alias, N., Siraj, S., Yaakub, M. Y., Ayob, J., \& Ishak, R. (2013). The potential of Youtube for teaching and learning in the performing arts. Procedia-Social and Behavioral Sciences, 103, 1118-1126.

Jill, M. D., Wang, D., \& Mattia, A. (2019). Are instructor generated YouTube videos effective in accounting classes? A study of student performance, engagement, motivation, and perception. Journal of Accounting Education, 47, 63-74.

Kacetl, J., \& Semradova, I. (2020). Reflection on blended learning and e-learning-case study. Procedia Computer Science, 176, 1322-1327.

Negara, H. R. P., Ibrahim, M., \& Etmy, D. (2020). Pelatihan Pembelajaran Daring (Google Classroom) bagi Guru MTs dan MI Nurul Yaqin Kelanjur. JPMB: Jurnal Pemberdayaan Masyarakat Berkarakter, 3(1), 66-79.

Nomor, S. E. M. (4). Tahun 2020 tentang Pelaksanaan Kebijakan Pendidikan dalam Masa Darurat Penyebaran CoronaVirus Disease (Covid-19). Jakarta: Menteri Pendidikan dan Kebudayaan Republik Indonesia.

Purwanto, A., Pramono, R., Asbari, M., Hyun, C. C., Wijayanti, L. M., \& Putri, R. S. (2020). Studi Eksploratif Dampak Pandemi COVID-19 Terhadap Proses Pembelajaran Online di Sekolah Dasar. EduPsyCouns: Journal of Education, Psychology and Counseling, 2(1), 1-12.

Raes, A., Detienne, L., Windey, I., \& Depaepe, F. (2020). A systematic literature review on synchronous hybrid learning: gaps identified. Learning Environments Research, 23(3), 269290. 
Rizun, M., \& Strzelecki, A. (2020). Students' acceptance of the Covid-19 impact on shifting higher education to distance learning in Poland. International Journal of Environmental Research and Public Health, 17(18), 6468.

Sari, L. (2020). UPAYA MENAIKKAN KUALITAS PENDIDIKAN DENGAN PEMANFAATAN YOUTUBE SEBAGAI MEDIA AJAR PADA MASA PANDEMI COVID-19. Jurnal Tawadhu, 4(1), 1074-1084.

Sari, M., Nawawi, N., \& Darmawan, H. (2020). Analisis pembelajaran di era pandemik (covid-19) pada program studi pendidikan biologi ikip pgri pontianak. Jurnal Pendidikan Teknologi Informasi dan Komputer (JPTIK), 2(1), 1-7.

Suhada, I., Kurniati, T., Pramadi, A., \& Listiawati, M. (2020). Pembelajaran daring berbasis Google Classroom mahasiswa pendidikan biologi pada masa wabah Covid-19. Digital Library UIN Sunan Gunung Djati, 1-10. 